\title{
KEDUDUKAN PERJANJIAN BANGUN GUNA SERAH (BUILD OPERATE AND TRANSFER/BOT) DALAM HUKUM TANAH NASIONAL
}

\author{
Anita Kamilah \\ Dosen Fakultas Hukum Universitas Suryakancana, Jl. Pasir Gede Raya Cianjur, Telp: (0263) 262773, \\ Hp: 085624734073, E-mail: anita.kamilah@yahoo.co.id
}

\begin{abstract}
ABSTRAK
Negara Indonesia merupakan negara hukum yang bertujuan untuk mewujudkan masyarakat adil dan makmur. Guna mewujudkan tujuan tersebut, dilakukan pembangunan nasional secara bertahap dan berkelanjutan. Pelaksanaan pembangunan tersebut selain perlu didukung oleh dana juga ketersediaan lahan strategis. Keterbatasan keduanya dapat dilakukan melalui konsep BOT, sebagai suatu perjanjian antara pemilik hak atas tanah dengan investor, dimana pemilik hak atas tanah menyerahkan studi kelayakan, pembangunan, pengoperasian kepada investor pada suatu jangka waktu tertentu, dengan ketentuan apabila masa BOT telah habis, tanah beserta bangunan, serta kelengkapan bangunan diserahkan kepada pemilik hak atas tanah, sehingga baik pemilik hak atas tanah maupun pihak investor yang mendanai pembangunan objek BOT memiliki keuntungan.
\end{abstract}

Kata Kunci : Pembangunan Nasional, Tanah, Dana, BOT.

\begin{abstract}
Indonesia is a state based on a rule of law the goal of which is to realize a just, prosperous, and materially and spiritually equal people. To realize the goal, progressively, sustainable national development has been conducted. The implementation of the development needs, besides from money, the availability of strategic land. To bridge the lack in both of them, BOT concept can be applied, as an agreement between the owner of land right and investor, where the former provides a feasibility study, building, and operation to the latter for a specified period of time, on the condition that when the BOT period of time has expired then the land together with the buildings and their appliances should be transferred to the former, so that both the owner of land right and the investors are mutually benefited.
\end{abstract}

Keywords : National Development, Land, Capital, BOT. 


\section{PENDAHULUAN}

Peran negara yang utama dalam setiap konstitusi atau UndangUndang Dasar, mewujudkan cita-cita bangsa itu sendiri, dan cita-cita bangsa Indonesia tercantum dalam Undang-Undang Dasar 1945 sebagai dasar konstitusi Negara Republik Indonesia, untuk mewujudkan kesejahteraan seluruh warga negara Indonesia serta membentuk negara kesejahteraan.

Bagir Manan menyebutkan bahwa dalam prinsip negara kesejahteraan pemerintah tidak semata-mata sebagai penjaga keamanan atau ketertiban masyarakat, tetapi memikul tanggung jawab utama untuk mewujudkan keadilan sosial, kesejahteraan umum, dan sebesar-besarnya kemakmuran rakyat (Bagir Manan, 1996 : 16).

Berkaitan dengan itu, Sjachran Basah mengatakan pemerintah tidak semata-mata di bidang pemerintahan saja, melainkan harus melaksanakan kesejahteraan sosial dalam rangka mencapai tujuan negara melalui pembangunan nasional (Sjachran Basah, $1986: 3$ ).

Negara Indonesia menunjukkan keinginan kuat untuk membentuk negara kesejahteraan tersebut sebagaimana diamanatkan dalam Pembukaan Undang-Undang Dasar 1945, yaitu: “Membentuk suatu pemerintah negara Indonesia yang melindungi segenap bangsa Indonesia dan seluruh tumpah darah Indonesia, dan untuk memajukan kesejahteraan umum, mencerdaskan kehidupan 
bangsa, serta ikut melaksanakan ketertiban dunia yang berdasarkan kemerdekaan, perdamaian abadi dan keadilan sosial" (C.F.G. Sunaryati Hartono, $1991: 2$ ).

Negara Republik Indonesia melakukan pembangunan disegala bidang kehidupan, termasuk pembangunan di bidang hukumnya untuk mencapai tujuan yang diamanatkan Pembukaan Undang-Undang Dasar 1945. Salah satu asas terpenting dari batang tubuh Undang-Undang Dasar 1945, yang menjadi landasan pembangunan ekonomi Indonesia diatur dalam Pasal 33 ayat (3) Undang-Undang Dasar 1945 yang menyatakan bahwa: “Bumi dan air dan kekayaan alam yang terkandung di dalamnya dikuasai oleh negara dan dipergunakan untuk sebesar-besarnya kemakmuran rakyat" (Mochtar Kusumaatmadja, 2006 : 189).

Sejalan dengan hal di atas, maka hakikat untuk sebesar-besarnya kemakmuran rakyat dan kesejahteraan rakyat dalam penguasaan, pemilikan, penggunaan, dan pemanfaatan sumber daya agraria harus didukung oleh penataan sistem hukum yang berpihak kepada rakyat. Guna mewujudkan amanat tersebut, setelah melalui proses dan waktu yang cukup panjang, maka pada tanggal 24 September 1960 Pemerintah dan DPR mengesahkan Undang-Undang No. 5 Tahun 1960 tentang Peraturan Dasar Pokok-pokok Agraria atau yang lajim disebut UUPA. Dengan berlakunya UUPA, maka di Indonesia terjadi perubahan yang fundamental di bidang agraria, yaitu perubahan dari hukum agraria kolonial menjadi hukum agraria nasional yang didasarkan atas hukum adat 
tentang tanah, sederhana, menjamin kepastian hukum bagi seluruh rakyat Indonesia, tidak mengabaikan unsur-unsur yang bersandar pada hukum agama, memberi kemungkinan supaya bumi, air, dan ruang angkasa dapat mencapai fungsinya dalam membangun masyarakat yang adil dan makmur, memperhatikan perkembangan jaman dalam kaitannya dengan soal agraria, mewujudkan penjelmaan dari Pancasila dan cita-cita bangsa seperti tercantum dalam Pembukaan Undang-Undang Dasar 1945, serta melaksanakan ketentuan Pasal 33 UUD 1945 (Muchsin, et.al., 2007 : 49-50).

Pembangunan nasional sebagai rangkaian upaya pembangunan yang berkesinambungan, yang meliputi seluruh aspek kehidupan masyarakat bangsa dan negara untuk melaksanakan tugas mewujudkan tujuan nasional sebagaimana dirumuskan dalam Pembukaan Undang-Undang Dasar Negara Republik Indonesia Tahun 1945 tersebut, membutuhkan tanah yang cukup luas sedangkan persediaan tanah sangat terbatas baik jumlah maupun luasnya yang bersifat tetap dan tidak bertambah dalam segala dimensi kebutuhan manusia. Keterbatasan sumber daya tanah, berhadapan dengan peningkatan kebutuhan tanah bagi pelaksanaan pembangunan, di satu sisi membawa dampak positif meningkatnya harga tanah, tetapi di pihak lain membawa dampak negatif menjadi salah satu pemicu timbulnya sengketa/konflik pertanahan. Di samping itu, dalam kaitannya dengan peningkatan permintaan akan tanah, tidak jarang terdapat sekelompok orang yang sengaja mempergunakan kesempatan untuk mengambil keuntungan 
pribadi dengan mengambil alih tanah masyarakat tanpa memperhatikan rasa keadilan.

Selain tanah, meningkatnya pembangunan nasional yang bertitik berat pada bidang ekonomi, membutuhkan pula penyediaan dana yang cukup besar. Kebutuhan dana untuk pembangunan infrastruktur sekitar dua tahun kebelakang saja diperkirakan membutuhkan dana sekitar Rp. 700 triliun sampai dengan Rp. 1.030 triliun, dan sekitar Rp. 200 triliun dapat didanai dari APBN, artinya pemerintah hanya mampu membiayai sekitar $20 \%$, sedangkan sekitar Rp. 600 triliun atau sekitar $80 \%$ diharapkan partisipasi dari investor lokal atau internasional (Budi Santoso, $2008: 1-2$ ).

Mengingat keterbatasan pemerintah melalui APBN, maupun daerah melalui APBD dalam menyediakan pendanaan untuk pembangunan infrastrukturnya, maka perlu dikembangkan hubungan kemitraan yang saling menunjang dan menguntungkan antara perusahaan besar dan kecil baik perusahaan nasional maupun perusahaan asing dalam rangka memperkuat struktur ekonomi nasional melalui model-model atau pola-pola baru sebagai alternatif pembiayaan pembangunan proyek-proyek pemerintah. Salah satu alternatif pembiayaan proyek infrastruktur, yang dapat menjembatani kesulitan pembiayaan pembangunan baik karena keterbatasan tanah atau lahan yang strategis maupun dana adalah dengan mengundang pihak swasta untuk 
berpartisipasi dalam pengadaan proyek pemerintah melalui sistem Bangun Guna Serah (Build Operate and Transfer/BOT).

BOT merupakan istilah yang relatif baru dalam sistem hukum nasional, tetapi memiliki peran yang cukup besar dalam mendukung pelaksanaan pembangunan nasional dalam menjembatani keterbatasan penyediaan lahan strategis maupun keterbatasan dana/modal, namun demikian mengingat tanah yang menjadi objek BOT tidak didaftar sebagaimana hak-hak atas tanah lainnya yang lahir dari suatu perjanjian, seperti perjanjian kredit dengan jaminan hak tanggungan, menyebabkan hak atas tanah yang menjadi objek perjanjian BOT tidak sekuat hak-hak atas tanah lainnya. Adapun permasalahan-permasalahan yang diteliti adalah bagaimanakah ketentuan Bangun Guna Serah (Build Operate and Transfer/BOT) setelah berlakunya Undang-Undang No. 5 Tahun 1960, dan bagaimanakah pengaturan perlindungan hukum para pihak dalam perjanjian BOT yang tanahnya tidak terdaftar dalam sistem pendaftaran tanah.

\section{PEMBAHASAN}

A. Ketentuan Bangun Guna Serah (Build Operate And Transfer/BOT) Setelah Berlakunya Undang-Undang No. 5 Tahun 1960.

Berbagai aliran filsafat hukum yang ada, dalam mengkaji ketentuan Bangun Guna Serah (Build Operate And Transfer/BOT) setelah berlakunya Undang-Undang No. 5 Tahun 1960, pisau analisisnya bertitik tolak pada 
konsep negara hukum, karena teori negara hukum menjunjung tinggi adanya sistem hukum yang menjamin kepastian hukum dan perlindungan hak-hak rakyat, termasuk dalam hal ini adalah hak-hak atas pemanfaatan sumber daya agraria.

Secara normatif ditegaskan dalam batang tubuh konstitusi Pasal 1 ayat (3) Undang-Undang Dasar 1945 Amandemen Ketiga yang menyebutkan bahwa : “Negara Indonesia adalah negara hukum" (Philipus M. Hadjon, $1996: 75)$.

Adapun konsep negara hukum yang dianut Indonesia adalah konsep negara hukum modern/negara kesejahteraan (welfare state) dimana pemerintah turut campur secara aktif dalam mewujudkan masyarakat adil dan makmur baik spiritual maupun materiil berdasarkan Pancasila dan Undang-Undang Dasar 1945, sehingga disebut negara hukum Pancasila (Sjachran Basah, 1986 : 11).

Konsep negara hukum sebagai cita hukum (rechts idee) Indonesia, mengandung prinsip kepastian hukum yang ada baik dalam konsep rechtsstaat dan prinsip keadilan yang ada dalam konsep rule of law (Mahfud M.D., 2006 : 26).

Pembangunan sistem hukum Indonesia banyak mendapatkan pengaruh dari pandangan aliran positivisme hukum yang dipelopori John Austin sebagaimana terlihat dalam Pasal 15 Algemene Bepaling van Wetgeving 
bahwa hakikat hukum adalah perintah penguasa. Selain itu, pembangunan hukumnya mendapat pengaruh dari aliran hukum positif murni, yang dipelopori oleh Hans Kelsen, yang dikenal dengan Teori Jenjang (Stufenbau Theorie), yang menyebutkan bahwa sistem hukum hakikatnya merupakan sistem hierarkis yang tersusun dari yang terendah hingga peringkat tertinggi yang berbentuk suatu piramida. Hukum yang lebih rendah harus bersumber dan tidak boleh bertentangan dengan hukum yang lebih tinggi. Sifat bertentangan dari hukum yang lebih rendah mengakibatkan batalnya daya berlaku hukum itu. Sebaliknya, hukum yang lebih tinggi merupakan dasar dan sumber dari hukum yang lebih rendah. Semakin tinggi kedudukan hukum dalam peringkatnya semakin abstrak dan umum sifat norma yang dikandungnya, dan semakin rendah peringkatnya, semakin nyata dan operasional sifat norma yang dikandungnya (Lili Rasjidi, 1985 : 34-38). Norma yang paling tinggi, menduduki puncak piramida disebut Hans Kelsen dengan Grundnorm (norma dasar).

Aliran hukum positif murni ini mendapat pengaruh kuat dari aliran pemikiran hukum pendahulunya, yaitu legisme yang berkembang pada abad pertengahan, yang menyamakan hukum dengan undang-undang sebagai pokok pikirannya. Persepsi ini dianut oleh Hans Kelsen, Jellinek, Paul Laband, serta ahli-ahli hukum Jerman lainnya (Lili Rasjidi dan I.B. Wyasa Putra, $2003: 21$ ). 
Selain itu, pembangunan sistem hukum Indonesia pun mendapat pengaruh yang luas dari aliran filsafat hukum Sociological Jurisprudence yang mencoba mengakomodasikan semua sumber material hukum dan nilai-nilai yang menjadi tujuan hukum dari masing-masing aliran filsafat hukum yang ada (Darji Darmodiharjo dan Sidharta, 1996 : 72).

Aliran Sociological Jurisprudence merupakan salah satu aliran yang melakukan berbagai pendekatan, dimana yang menjadi pendasar mazhab ini adalah Roscoe Pound, Eugen Ehrlich, Benjamin Cardozo, Kantorowics, Gurvitch, dan lain-lain. Inti pemikiran mazhab yang berkembang di Amerika ini menyebutkan bahwa hukum yang baik adalah hukum yang sesuai dengan hukum yang hidup di dalam masyarakat. Sesuai di sini berarti bahwa hukum itu harus mencerminkan nilai-nilai yang hidup di dalam masyarakat (Living Law) (Lili Rasjidi, 1985 : 70).

Berbeda dengan pandangan aliran positivisme hukum, menurut aliran Sociological Jurisprudence, undang-undang sebagai ketentuan hukum yang tertulis memang diperlukan untuk menjamin kepastian hukum serta menghindarkan tindakan sewenang-wenang dari kekuasaan yang bersifat absolut, namun demikian merujuk pendapat yang dikemukakan oleh Eugen Ehrlich, yang terkenal dengan konsep living law-nya, bahwa hukum positif akan memiliki daya berlaku yang efektif apabila berisikan dan selaras dengan 
hukum yang hidup dalam masyarakat (Lili Rasjidi dan Ira Thania Rasjidi, $2002: 66)$.

Hal senada dikemukakan juga oleh Friedrich Carl Von Savigny, pendasar mazhab sejarah, yang memiliki konsep "Das Recht wird nicht gemacht, est ist und wird mit dem volke", yaitu bahwa : "Hukum itu tidak dibuat, akan tetapi tumbuh dan berkembang bersama masyarakat". Pandangannya bertitik tolak bahwa di dunia ini terdapat banyak bangsa, dan tiap-tiap bangsa tadi memiliki suatu "volksgeist/jiwa bangsa", dimana jiwa bangsa ini berbeda, baik menurut waktu maupun menurut tempat" (Lili Rasjidi, 1985 : 66).

Pandangan penting lainnya dari Roscoe Pound sebagai salah satu penganut aliran Sociological Jurisprudence, dikenal dengan teorinya: "Hukum sebagai alat untuk memperbaharui/merekayasa masyarakat (Law as a tool of social engineering)". Menurut Roscoe Pound, hukum harus dapat melindungi kepentingan umum (public interest), kepentingan masyarakat (social interest), dan kepentingan pribadi (private interest), tidak sekadar melestarikan status quo (Darji Darmodiharjo dan Shidarta, 2004 : 197).

Pembaharuan hukum tersebut menurut Mochtar Kusumaatmadja, dapat dilakukan melalui sarana berupa undang-undang, yurisprudensi, atau undang-undang dan yurisprudensi secara sekaligus. Hal ini berarti dapat dilakukan dengan pembaharuan sistem hukum, yaitu melalui proses legislasi 
yang dilakukan oleh pembuat undang-undang dan hakim (Lili Rasjidi dan Ira Thania Rasjidi, 2007 : 78-79).

Teori Hukum Pembangunan Mochtar Kusumaatmadja yang dikenal sebagai pelopor Mazhab Unpad, merupakan teori hukum yang mentransformasi konsep pembangunan hukum dari Amerika yang dipelopori oleh Roscoe Pound. Namun demikian, meskipun Mochtar Kusumaatmadja mengadopsi pandangan Roscoe Pound, tetapi menolak konsepsi mekanis dari konsepsi law as a tool of social engineering, dan menggantikan istilah alat (a tool) dengan istilah sarana (Lili Rasjidi dan I.B. Wyasa Putra, 2003 : 183), karena selain pengertian "sarana" lebih luas dari "alat" (a tool), juga disebabkan karena beberapa alasan :

1. Apabila konsep pembangunan hukum di Amerika dibandingkan dengan teori hukum pembangunan di Indonesia, terdapat perbedaan pandangan. Dalam penerapan sistem hukum di Indonesia, pengembangan dan pembangunan hukum lebih ditekankan pada pemberlakuan undangundang dibandingkan dengan yurisprudensi. Hal ini berbeda dengan di Amerika, dimana kedudukan yurisprudensi jauh lebih penting dari Indonesia.

2. Selain itu juga, penggunaan peranan hukum yang diistilahkan sebagai “alat rekayasa masyarakat" cenderung ditolak dan ditentang, karena lebih bersifat mekanistis dan menjurus pada pengakuan paham legisme 
sebagaimana pernah diadakan pada jaman Hindia Belanda, dan di Indonesia ada sikap yang menunjukkan kepekaan masyarakat untuk menolak penerapan konsep itu (Munir Fuady, 2007:165), (Mochtar Kusumaatmadja, 1976 : 9-10).

Apabila konsep-konsep filsafat di atas diterapkan dalam tataran yang lebih konkrit, maka cukup banyak asas-asas dan prinsip-prinsip yang terkandung dalam Undang-Undang Dasar 1945 dan Mukadimahnya yang dijadikan pedoman dalam melakukan pembaharuan hukum nasional yang mengacu pada prinsip-prinsip hukum umum yang diterima oleh bangsabangsa di dunia.

Berlandaskan pada konsep kefilsafatan di atas, sebagai negara yang didasarkan atas hukum, salah satu asas terpenting yang menjadi dasar dalam usaha pembangunan dan pembinaan hukum nasional, di antaranya ketentuan Pasal 33 Undang-Undang Dasar 1945 khususnya ayat (3) yang menyatakan bahwa: "Bumi dan air dan kekayaan alam yang terkandung di dalamnya dikuasai oleh negara dan dipergunakan untuk sebesar-besarnya kemakmuran rakyat", yang telah diwujudkan melalui pengundangan Undang-Undang No.

5 Tahun 1960 Tentang Peraturan Dasar Pokok-pokok Agraria/UUPA (Mochtar Kusumaatmadja, $2006: 189$ ).

Pengertian "dikuasai" negara sebagaimana dinyatakan dalam Pasal 33 ayat (3) UUD 1945 tidak dijelaskan secara rinci dalam penjelasan, baik 
penjelasan umum maupun penjelasan pasal demi pasal. Hal ini memungkinkan hak menguasai negara itu ditafsirkan atas berbagai pemahaman, tergantung dari sudut pandang dan kepentingan yang menafsirkan. Dalam Kamus Bahasa Indonesia yang disusun oleh Poerwadarminta, kata "menguasai" berarti kedudukan berkuasa atas sesuatu atau memegang kekuasaan atas sesuatu. Mengacu pada ketentuan konstitusi di atas, berarti hak menguasai negara meliputi semua tanah, tanpa terkecuali, sehingga negara memegang kekuasaan atas sumber-sumber daya agraria sebagaimana tertera dalam Pasal 33 ayat (3) Undang-Undang Dasar 1945 (W.J.S. Poerwadarminta, 1976 : 528).

Notonagoro, dalam buku "Politik Hukum dan Pembangunan Agraria di Indonesia", menetapkan adanya tiga macam bentuk hubungan antara negara dengan bumi, air, dan ruang angkasa, yaitu sebagai berikut :

1. Negara sebagai subjek, diberi kedudukan tidak sebagai perorangan tetapi sebagai negara. Dengan demikian, negara sebagai badan kenegaraan, badan yang publiekrechtelik, dan dalam bentuknya seperti ini negara tidak mempunyai kedudukan yang sama dengan perorangan;

2. Negara sebagai subjek, yang dipersamakan dengan perorangan sehingga hubungan antara negara dengan bumi dan lain sebagainya itu "sama" dengan hak perorangan atas tanah; 
3. Hubungan antara negara "langsung" dengan bumi dan sebagainya tidak dalam kedudukannya sebagai negara yang memiliki, tetapi sebagai negara yang dipersonifikasikan dari seluruh rakyat sehingga dalam konsep ini negara tidak lepas dari rakyat. Negara hanya menjadi pendiri dan pendukung kesatuan-kesatuan rakyat (Maria S.W. Sumardjono, 1982 ; 12).

Mengacu pada pendapat Notonagoro di atas, maka bentuk hubungan antara negara dengan bumi, air, dan ruang angkasa yang sesuai dengan makna hak menguasai negara adalah bentuk hubungan yang ketiga. Hubungan tersebut menurut Pasal 1 ayat (3) UUPA adalah hubungan yang abadi. Dalam arti, bahwa selama bangsa Indonesia masih ada dan selama bumi, air, dan ruang angkasa itu masih ada, maka hubungan itu tidak akan terputus oleh kekuasaan apapun.

Lebih lanjut menurut Maria S.W. Sumardjono, menyebutkan bahwa istilah "menguasai" sama sekali berbeda dengan istilah "dimiliki" sebagaimana dipahami dalam konsep Domeinverklaring menurut Agrarisch Besluit Stb. 1870 No. 118, yang menyatakan bahwa tanah-tanah yang tidak dapat dibuktikan kepemilikannya menjadi milik negara, yang membawa akibat terhadap rakyat perorangan yang tidak mungkin mempunyai milik perseorangan atas tanah. Hal senada disampaikan oleh Budi Harsono, yang menyebutkan bahwa konsep "dikuasai" bukan "dimiliki", karena pemilikan 
atas tanah oleh negara bukanlah merupakan konsep hukum tata negara yang modern, melainkan merupakan konsep hukum tata negara feodal ( $R$. Soeprapto, $1986: 10)$

Guna mencegah adanya berbagai penafsiran berkaitan dengan ketentuan Pasal 33 ayat (3) Undang-Undang Dasar 1945, maka Pasal 2 ayat (2) Undang-Undang No. 5 Tahun 1960 Tentang Peraturan Dasar Pokokpokok Agraria telah memberikan tafsiran resmi kata "menguasai" bukanlah berarti dimiliki, akan tetapi adalah pengertian yang memberikan wewenang kepada Negara sebagai organisasi kekuasaan dari bangsa Indonesia itu, untuk pada tingkatan tertinggi :

a. Mengatur dan menyelenggarakan peruntukan, penggunaan, persediaan dan pemeliharaan bumi, air, dan ruang angkasa tersebut;

b. Menentukan dan mengatur hubungan-hubungan hukum antara orangorang dengan bumi, air, dan ruang angkasa;

c. Menentukan dan mengatur hubungan-hubungan hukum antara orangorang dan perbuatan-perbuatan hukum yang mengenai bumi, air, dan ruang angkasa.

Dengan demikian, dipilihnya kata "dikuasai" dalam Pasal 33 ayat (3) Undang-Undang Dasar 1945 bukan suatu kebetulan melainkan merupakan suatu hasil pengolahan rasional terhadap pandangan filosofis, dan politik atas masalah-masalah kenegaraan yang mendasar (R. Soeprapto, $1986: 10$ ). 
Wewenang yang bersumber pada hak menguasai negara tersebut sesuai ketentuan Pasal 2 ayat (3) UUPA, harus digunakan untuk mencapai sebesarbesarnya kemakmuran rakyat dalam arti kebangsaan, kesejahteraan, kemerdekaan dalam masyarakat dan negara hukum Indonesia yang merdeka, berdaulat, adil, dan makmur. Dengan demikian, konsepsi dan ketentuanketentuan pokok agraria, yang merupakan penjabaran sila-sila Pancasila di bidang pertanahan, yang juga merupakan penjabaran Politik Pertanahan Nasional sebagaimana digariskan dalam Pasal 33 ayat (3) Undang-Undang Dasar 1945 tersebut, masih relevan dijadikan sebagai landasan hukum bagi penyelesaian pembangunan hukum tanah nasional.

Sesuai Pasal 4 ayat (1) UUPA, bahwa : "Atas dasar hak menguasai dari negara sebagaimana dimaksud dalam Pasal 2 ditentukan adanya macammacam hak atas permukaan bumi, yang disebut tanah, yang dapat diberikan kepada dan dipunyai oleh orang-orang, baik sendiri maupun bersama dengan orang lain serta badan-badan hukum", maka pengertian tanah yang dimaksud di sini bukan mengatur tanah dalam segala aspeknya, melainkan hanya mengatur salah satu aspek saja, yaitu tanah dalam pengertian yuridis sebagai permukaan bumi saja. Adapun hak atas tanahnya adalah hak atas sebagian permukaan bumi, yang berbatas, berdimensi dua dengan ukuran panjang dan lebar, yang memberi wewenang kepada pemegang haknya untuk mem- 
pergunakan atau mengambil manfaat dari tanah yang dihakinya (Urip Santoso, $2005: 10)$.

Perkataan "mempergunakan" mengandung pengertian bahwa hak atas tanah itu dapat dipergunakan untuk kepentingan mendirikan bangunan, sedangkan perkataan "mengambil manfaat" mengandung pengertian bahwa hak atas tanah itu dipergunakan untuk kepentingan bukan mendirikan bangunan, misalnya untuk pertanian, perikanan, peternakan, dan perkebunan (Urip Santoso, 2005 : 10). Atas dasar ketentuan Pasal 4 ayat (2) UUPA, kepada pemegang hak atas tanah diberi wewenang untuk mempergunakan tanah yang bersangkutan, demikian pula tubuh bumi dan air, serta ruang yang di atasnya sekadar diperlukan untuk kepentingan langsung yang berhubungan dengan penggunaan tanah itu dalam batas-batas menurut UUPA dan peraturan-peraturan hukum yang lebih tinggi.

Selain itu, atas dasar hak menguasai negara, dikenal macam-macam hak atas tanah sebagaimana diatur dalam Pasal 16 UUPA tersebut adalah : (1) Hak Milik, (2) Hak Guna Usaha; (3) Hak Guna Bangunan; (4) Hak Pakai; (5) Hak Sewa; (6) Hak Membuka Tanah; (7) Hak Memungut Hasil Hutan; dan (8) Hak-hak lain yang tidak termasuk dalam hak-hak atas tanah sebelumnya yang akan ditetapkan dengan undang-undang dan sifatnya sementara sebagaimana disebutkan dalam Pasal 53 UUPA, yaitu : (1) Hak 
Gadai; (2) Hak Usaha Bagi Hasil; (3) Hak Menumpang; dan (4) Hak Sewa Tanah Pertanian.

Hak Pengelolaan sebagai hak atas tanah tidak mendapat pengaturan dalam Pasal 16 UUPA. Hak Pengelolaan untuk pertama kali disebut dan diatur dalam Peraturan Menteri Agraria No. 9 Tahun 1965 tentang Pelaksanaan Konversi Hak Penguasaan Atas Tanah Negara dan Ketentuanketentuan tentang Kebijaksanaan Selanjutnya, yang kemudian diubah dengan Peraturan Menteri Dalam Negeri No. 5 Tahun 1974 tentang Ketentuanketentuan Mengenai Penyediaan dan Pemberian Hak Untuk Keperluan Perusahaan juncto Peraturan Menteri Dalam Negeri No. 1 Tahun 1977 tentang Tata Cara Permohonan dan Penyelesaian Pemberian Hak Atas Bagian-bagian Tanah Hak Pengelolaan Serta Pendaftarannya.

Adapun yang dimaksud dengan Hak Pengelolaan, yaitu hak penguasaan atas tanah negara, dengan maksud disamping untuk mempergunakan sendiri oleh si pemegang juga oleh pemegang memberikan sesuatu hak kepada pihak ketiga, dan kepada si pemegang salah satunya diberikan wewenang untuk menyerahkan bagian-bagian dari tanah tersebut kepada pihak ketiga, menurut persyaratan yang ditentukan oleh perusahaan pemegang hak tersebut, yang meliputi segi-segi peruntukannya, penggunaan, jangka waktu dan keuangannya, dengan Hak Milik, Hak Guna Bangunan, atau Hak Pakai dengan ketentuan bahwa pemberian hak atas tanah kepada 
pihak ketiga yang bersangkutan dilakukan oleh pejabat-pejabat yang berwenang menurut Peraturan Menteri Dalam Negeri No. 6 Tahun 1972 tentang Pelimpahan Wewenang Pemberian Hak Atas Tanah Sesuai dengan Peraturan Perundangan Agraria yang Berlaku; dan (4) Menerima uang pemasukan/ganti rugi, dan atau wajib tahunan (H. Ali Achmad Chomzah, 2000 : 55), dan (Arie Sukanti Hutagalung dan Markus Gunawan, 2009 : $52-53)$.

Mengkaji arti Hak Pengelolaan, pemegang hak pengelolaan disamping dapat mempergunakan sendiri haknya, juga dapat memberikan sesuatu hak kepada pihak ketiga, menurut persyaratan yang ditentukan oleh perusahaan pemegang hak tersebut, salah satunya melalui konsep BOT.

Hak milik sebagaimana diatur dalam Pasal 20 UUPA sebagai hak turun temurun, terkuat dan terpenuh yang dapat dipunyai orang atas tanah, dengan mengingat ketentuan dalam Pasal 6".

Menurut John Locke, sebagai orang pertama yang memberikan perhatiannya terhadap hak milik, bahwa hak milik atas tanah merupakan bagian dari hak milik pribadi sebagai bagian dari hak asasi manusia yang kodrati, yang menjadi dasar untuk mempertahankan hidup, kebebasan, dan kemerdekaannya (Locke, John, 1960 : 9).

Amandemen Ketiga Undang-Undang Dasar 1945 pun, menyebutkan bahwa setiap orang berhak untuk hidup serta mempertahankan hidup dan 
kehidupan serta mengembangkan diri melalui pemenuhan kebutuhan dasar (Aslan Noor, 2006 : 329). Berpijak dari hal tersebut, pemilik hak atas tanah baik pemerintah maupun perorangan dapat mengoptimalkan tanah yang dihakinya untuk melakukan kerjasama dengan pihak ketiga salah satunya melalui perjanjian Bangun Guna Serah (Build Operate and Transfer/BOT).

Bangun Guna Serah (Build Operate and Transfer/BOT) merupakan suatu perjanjian, sehingga memiliki kaitan dengan Buku III KUH Perdata tentang Perikatan (van verbintenissen). Perikatan adalah hubungan hukum antara sejumlah terbatas subjek-subjek hukum, sehubungan dengan itu seseorang atau beberapa orang daripadanya (debitur atau para kreditur) mengikatkan dirinya untuk bersikap menurut cara-cara tertentu terhadap pihak yang lain, yang berhak atas sikap yang demikian itu (R. Setiawan, $1978: 2)$.

Menurut ketentuan Pasal 1233 KUH Perdata, perikatan bersumber dari perjanjian dan undang-undang. Perikatan yang bersumber dari perjanjian diatur dalam titel II Pasal 1313 sampai dengan Pasal 1352, dan titel V sampai dengan titel XVIII Pasal 1457 sampai dengan Pasal 1864 Buku III KUH Perdata, sedangkan perikatan yang bersumber dari undang-undang diatur dalam titel III Pasal 1352 sampai dengan Pasal 1380 Buku III KUH Perdata. 
Perikatan yang bersumber dari undang-undang, menurut Pasal 1352 KUH Perdata dibedakan atas perikatan yang lahir dari undang-undang saja (uit de wet allen) dan perikatan yang lahir dari undang-undang karena perbuatan manusia (uit de wet door's mensen toedoen). Kemudian perikatan yang lahir dari undang-undang karena perbuatan manusia menurut Pasal 1353 KUH Perdata dibedakan lagi atas perbuatan yang sesuai dengan hukum (rechtmatige) dan perbuatan yang melawan hukum (onrechtmatige). Perbuatan yang sesuai dengan hukum contohnya pengurusan kepentingan orang lain secara sukarela (zaakwaarnening), dan pembayaran yang tidak ada kewajiban utangnya (onvershuldigde betaling).

Sumber perikatan yang berasal dari perjanjian dan undang-undang tersebut, menurut Diephuis, Asser dan Suyling sebagaimana dikutip R. Soetojo Prawirohamidjojo dalam bukunya Hukum Perikatan mengatakan bahwa : "Antara perikatan yang bersumber pada perjanjian dan perikatan yang bersumber pada undang-undang pada hakikatnya tidak ada perbedaan, sebab semua perikatan meskipun bersumber dari perjanjian pada hakikatnya baru mempunyai kekuatan sebagai perikatan karena diakui oleh undangundang dan jika terjadi pelanggaran dalam pelaksanaannya akan mendapat sanksi dari undang-undang (R. Soetojo Prawirohamidjojo, 1979 : 20).

Meskipun demikian, menurut penulis-penulis yang lebih muda seperti Van Brakel, Losecaat - Vermeer dan Hofmann - Opstal, kedua macam 
perikatan itu tetap ada perbedaannya. Pada perikatan yang bersumber dari undang-undang, perikatan itu diciptakan secara langsung karena suatu keadaan tertentu, perbuatan atau kejadian dan membebankan suatu kewajiban dengan tidak menghiraukan kehendak orang yang harus memenuhinya, sedangkan pada perikatan yang bersumber dari perjanjian, meskipun mendapat sanksi dari undang-undang, tetapi keharusan untuk memenuhi kewajiban atas perjanjian tersebut barulah tercipta setelah yang bersangkutan yang harus memenuhinya memberikan persetujuan atau menghendakinya ( R. Soetojo Prawirohamidjojo, 1979 : 20).

Jika konsep Diephuis, Asser dan Suyling diimplementasikan pada perjanjian Bangun Guna Serah (Build Operate and Transfer/BOT), maka perjanjian BOT meskipun merupakan perikatan yang bersumber dari perjanjian antara para pemilik hak atas tanah dengan pihak investor, tetapi perjanjian yang dilakukan oleh para pihak tersebut baru memiliki kekuatan sebagai perikatan, jika memenuhi ketentuan yang telah ditentukan undangundang. Undang-undang dalam hal ini salah satunya sebagaimana diatur dalam Pasal 1320 KUH Perdata yang menentukan bahwa syarat sahnya perjanjian termasuk perjanjian BOT, jika memenuhi syarat (1) Sepakat mereka yang mengikatkan dirinya; (2) Kecakapan untuk membuat suatu perikatan; (3) Memenuhi suatu hal tertentu; serta (4) Memiliki suatu sebab yang halal. 
Jika syarat-syarat sahnya perjanjian sebagaimana diatur dalam Pasal 1320 KUH Perdata telah dipenuhi, maka berdasarkan Pasal 1338 ayat (1) KUH Perdata, perjanjian Bangun Guna Serah (Build Operate and Transfer/BOT) telah memiliki kekuatan hukum yang sama dengan kekuatan undang-undang. Ketentuan Pasal 1338 ayat (1) KUH Perdata menyebutkan bahwa : "Semua persetujuan yang dibuat secara sah berlaku sebagai undangundang bagi mereka yang membuatnya". Namun demikian, meskipun perjanjian BOT merupakan perikatan yang bersumber dari perjanjian, jika terjadi pelanggaran atas perjanjian Bangun Guna Serah (Build Operate and Transfer/BOT) tersebut, sanksinya tetap diberikan oleh undang-undang. Salah satu contohnya, yaitu bahwa ketika salah satu pihak tidak melaksanakan perjanjian Bangun Guna Serah (Build Operate and Transfer/BOT), yang kemudian menyebabkan kerugian kepada pihak lainnya, maka sesuai dengan ketentuan Pasal 1239 KUH Perdata, pihak tersebut diwajibkan membayar ganti rugi.

Namun demikian, sesuai dengan pendapat Van Brakel, Losecaat Vermeer dan Hofmann - Opstal, meskipun pelanggaran terhadap pelaksanaan perjanjian Bangun Guna Serah (Build Operate and Transfer/BOT) itu akan mendapatkan sanksi dari undang-undang, tetapi sanksi itu baru dapat dibebankan kepada pihak yang disebutkan ingkar janji, 
jika pihak tersebut sebelumnya telah memberikan persetujuan, sehingga tidak ada tuntutan maupun sanksi tanpa ada persetujuan.

Berkaitan dengan sumber perikatan sebagaimana telah disebutkan di atas, para ahli hukum perdata memiliki pendapat yang sama bahwa sumber perikatan sebagaimana disebutkan dalam Pasal 1233 KUH Perdata, yaitu perjanjian dan undang-undang adalah kurang lengkap. Sumber perikatan yang lain adalah IImu Pengetahuan Hukum Perdata, hukum tidak tertulis (hukum kebiasaan), dan keputusan hakim (yurisprudensi) (Mariam Darus Badrulzaman, $1996: 10)$.

Tanpa mengabaikan peran penting dari sumber-sumber perikatan yang lainnya, dari sumber-sumber perikatan di atas, perjanjian merupakan salah satu sumber perikatan yang terpenting dalam mengembangkan hukum perjanjian, sebab sesuai dengan salah satu asas yang dianut dalam sistem hukum nasional Indonesia, yaitu asas kebebasan berkontrak, maka para pihak diberikan suatu kebebasan untuk membuat segala macam perikatan, baik perikatan yang bernama yang tercantum dalam titel $\mathrm{V}$ sampai dengan XVIII Buku III KUH Perdata maupun perikatan yang tidak bernama.

Berdasarkan asas kebebasan berkontrak yang disimpulkan dari Pasal 1338 ayat (1) KUH Perdata, maka lahir perjanjian Bangun Guna Serah (Build Operate and Transfer/BOT), yang dikenal sebagai perjanjian tidak bernama (onbenoemde overeenkomst), yaitu perjanjian yang tidak diatur 
secara khusus dalam undang-undang, tetapi tumbuh dan berkembang dalam kegiatan ekonomi Indonesia. Sebagai suatu perjanjian tidak bernama, sampai saat ini belum ada pengertian dan pengaturan secara khusus mengenai pembangunan suatu proyek milik pemerintah ataupun swata yang dibiayai melalui sistem Bangun Guna Serah (Build Operate and Transfer/BOT). Aturan yang digunakan saat ini adalah Pasal 1338 ayat (1) KUH Perdata, yang dikenal sebagai asas kebebasan berkontrak.

Namun demikian, sebagai gambaran dapat dirujuk pendapat Neal Bieker dan Cassie Boggs, yang memberikan pengertian BOT, adalah :

"A government or government entity enters into an agreement with a private sector company under which the company agrees to finance, design and build the facility at its own costs, and is given a concession, usually for a fixed period, to operate that facility and collect tolls or other revenues from its operation before transferring the facility back to the government at the end of the concession period. The intention is that the company is to receive sufficient revenues during the operational phase to service its debt incurred in designing and building the facility; to cover its working capital and maintennace cost; to repay its equity investors; and hopefully, also provide a reasonable profit its investors" (Bieker. Neil, Cessie Boggs, $1997: 1$ ).

Menurut Neal Bieker dan Cassie Boggs, bahwa bentuk kerjasama BOT dapat dilakukan jika pemerintah atau badan usaha milik pemerintah mengadakan suatu perjanjian dengan suatu perusahaan sektor swasta dimana perusahaan tersebut bersedia untuk membiayai, merancang, dan membangun suatu fasilitas atau proyek atas biaya sendiri, dan kepadanya diberikan hak konsesi, biasanya untuk suatu waktu yang telah ditentukan, hak untuk 
mengoperasikan fasilitas atau proyek tersebut dan mengumpulkan atau menyediakan barang-barang bagi kepentingan fasilitas atau proyek atau pendapatan lain dari pengoperasian proyek sebelum fasilitas atau proyek tersebut diserahkan kembali kepada pemerintah diakhir masa konsesi.

Berdasarkan uraian di atas, walaupun konsep BOT sebagai suatu perjanjian tidak diatur secara khusus oleh Buku III KUH Perdata tentang Perikatan (Van Verbintenissen), namun ketentuan Pasal 1338 yang dikenal dengan asas kebebasan berkontrak dapat dijadikan sebagai dasar berlakunya BOT.

Selain itu, mengingat objek BOT adalah tanah, maka kajian lain yang tidak dapat diabaikan adalah bagaimana pengaturan BOT dalam UndangUndang No. 5 Tahun 1960 Tentang Peraturan Dasar Pokok-pokok Agraria. Mengkaji uraian di atas, meskipun objek BOT adalah tanah, tetapi UUPA pun sama seperti Buku III KUH Perdata tentang Perikatan (Van Verbintenissen) tidak secara tegas memberikan pengaturan tentang BOT sendiri.

Berbeda ketika seseorang mendapatkan pemanfaatan hak pengelolan atas tanah yang dikuasai negara di antaranya dilandasi atas hak milik, hak guna bangunan, atau hak pakai. Kemudian, jika seseorang menguasai tanah negara atau tanah milik pihak ketiga untuk mendirikan bangunan, yang dikenal dengan Hak Guna Bangunan (HGB) sebagaimana diatur dalam Pasal 
35 UUPA, atau hak untuk menggunakan dan/atau memungut hasil dari tanah yang langsung dikuasai langsung oleh negara atau tanah milik orang lain, yang dikenal dengan Hak Pakai sebagaimana diatur dalam Pasal 41 UUPA, serta hak untuk menjaminkan tanah pada pihak lain yang dikenal dengan Hak Tanggungan Atas Tanah sebagaimana diatur dalam UndangUndang No. 4 Tahun 1996 Tentang Hak Tanggungan Atas Tanah dan Benda-benda yang Berkaitan dengan Tanah.

Namun demikian, meskipun UUPA tidak mengatur secara tegas tentang BOT, apabila mengkaji ketentuan Pasal 20 UUPA maupun Ketetapan MPR No. XVII/MPR/1998 dan Undang-Undang No. 39 Tahun 1999 Tentang Hak Asasi Manusia, dapat dijadikan landasan berlakunya ketentuan BOT, karena pemilikan atas tanah sebagai salah satu hak asasi manusia, dapat dimanfaatkan oleh pemiliknya dalam berbagai aspek kehidupan baik dalam aspek ekonomi, aspek sosial, termasuk dalam hubungannya dengan pembangunan melalui konsep BOT.

Selain itu, ketentuan Pasal 35 UUPA tentang Hak Guna Bangunan dapat menjadi dasar berlakunya BOT, karena apabila seseorang menggunakan tanah yang langsung dikuasai langsung oleh negara atau tanah milik orang lain, yang didasarkan pada Hak Pakai, maupun Hak Pengelolaan, lajimnya di atas tanah yang dimanfaatkan melalui konsep BOT tersebut, diletakkan Hak Guna Bangunan. 
Ketentuan UUPA lain yang dapat dijadikan dasar pemberlakuan konsep BOT adalah Pasal 5 UUPA, yang menyebutkan bahwa :

"Hukum Agraria yang berlaku atas bumi, air, dan ruang angkasa ialah hukum adat, sepanjang tidak bertentangan dengan kepentingan nasional dan negara, yang berdasarkan atas persatuan bangsa, dengan sosialisme Indonesia serta dengan peraturan-peraturan yang tercantum dalam undang-undang ini (maksudnya UUPA) dan dengan peraturan perundang-undangan lainnya, segala sesuatu dengan mengindahkan unsur-unsur yang bersandar pada hukum agama".

Ketentuan pasal tersebut dikenal dengan asas pemisahan horisontal, bahwa seseorang dapat mendirikan bangunan di atas tanah milik orang lain, yang penerapannya dapat terlihat secara jelas pada ketentuan Pasal 20, Pasal 35, Pasal 41 dan Hak Pengelolaan.

Berdasarkan asas pemisahan horisontal pengembangan pembangunan terutama di pusat-pusat perkotaan, dimana tanah makin terasa semakin sempit, sedangkan pertumbuhan penduduk makin meningkat dengan pesat, demikian juga untuk keperluan pembangunan kawasan-kawasan, seperti kawasan industri, kawasan perdagangan, pembangunan gedung atau bangunan perkantoran, tidak selalu harus dilakukan melalui pembebasan atau pencabutan hak atas tanah seperti yang dilakukan sekarang ini, yang justru merugikan hak-hak masyarakat. Dengan penerapan asas pemisahan horisontal ini, masyarakat luas tidak akan dirugikan dengan gerak pembangunan yang ada, serta akan memecahkan atau mencegah timbulnya masalah seperti “pengusuran/pembebasan tanah" yang dipaksakan agar pemilikan tanah dan 
bangunan di satu tangan, yang justru merugikan hak-hak masyarakat. Kepemilikan tanah dapat tetap ada pada pemilik tanah, sehingga untuk keperluan pembangunan perumahan atau suatu kawasan tidak selalu dilakukan melalui pembebasan tanah atau pencabutan hak atas tanah sebagaimana dilakukan sekarang ini, yang justru sering menimbulkan suatu masalah atau sengketa tanah, dimana pemilik tanah tidak dapat menerima untuk melepaskan hak atas tanah yang dimilikinya, karena tidak layaknya pemberian ganti ruginya.

Melalui asas pemisahan horisontal yang diwujudkan dalam konsep BOT tersebut masyarakat tetap dapat menikmati hasil tanahnya, melalui suatu kemitraan usaha dengan pemilik modal. Demikian juga, para pengusaha yang membutuhkan lahan untuk kegiatan usahanya tidak perlu memiliki suatu hak atas tanah, tetapi cukup menyewa kepada pemilik hak atas tanah. Dengan demikian, masyarakat pemilik hak atas tanah akan dengan sukarela menyerahkan tanahnya, karena tidak akan dirugikan dan tidak akan kehilangan haknya bahkan masyarakat dapat secara bersama-sama turut serta berpartisipasi dalam pelaksanaan pembangunan nasional, serta dapat memperoleh keuntungan dari pertambahan nilai tanah yang terjadi karena pembangunan tersebut, bahkan melalui konsep BOT ini, jika masa BOT atau konsesi telah berakhir, pemilik hak atas tanah dapat memiliki bangunan beserta fasilitas-fasilitas yang mendukung bangunan tersebut. 


\section{B. Perlindungan Hukum Para Pihak Dalam Perjanjian BOT Yang Tanahnya Tidak Terdaftar Dalam Sistem Pendaftaran Tanah.}

Negara Republik Indonesia adalah negara hukum berdasarkan Pancasila dan Undang-Undang Dasar 1945, yang memiliki tujuan mewujudkan tata kehidupan negara dan bangsa yang adil dan sejahtera, aman, tentram, dan tertib, serta menjamin kedudukan hukum yang sama bagi warga masyarakat.

Penegasan bahwa negara hukum adalah cita hukum (rechts idée) Indonesia yang secara normatif diatur dalam Pasal 1 ayat (3) UndangUndang Dasar 1945 amandemen ketiga, yang menyebutkan bahwa : “Negara Indonesia adalah negara hukum (rechtsstaat) tidak berdasar atas kekuasaan belaka (Machtsstaat)", dan "pemerintahan berdasar atas sistem konstitusi (hukum dasar) tidak bersifat absolutisme (kekuasaan yang tidak berbatas)".

Istilah negara hukum dalam bahasa asing adalah rechtsstaat dan the rule of law. Istilah rechtsstaat mulai populer di Eropa sejak abad XIX. Istilah rule of law mulai populer dengan diterbitkannya sebuah buku dari Albert Venn Dicey tahun 1885 dengan judul Introduction to the study of the law of the constitution. Konsep rechtsstaat bertumpu atas sistem hukum continental yang disebut civil law atau modern roman law, sedangkan konsep 
the rule of law bertumpu atas sistem hukum yang disebut common law (Philipus M. Hadjon, 1996 : 75-76).

Menurut M.C. Burkens, syarat-syarat dasar rechtsstaat adalah sebagai berikut :

“1. Asas legalitas, dimana setiap tindakan pemerintah harus didasarkan atas dasar peraturan perundang-undangan (wettelijke grondslag), dengan landasan ini undang-undang dalam arti formal dan Undang-Undang Dasar sendiri merupakan tumpuan dasar tindakan pemerintah. Dalam hubungan ini pembentukan undangundang merupakan bagian penting negara hukum.

2. Pembagian kekuasaan, syarat ini mengandung makna bahwa kekuasaan negara tidak boleh hanya bertumpu pada satu tangan.

3. Hak-hak dasar (grondrechten), dimana hak-hak dasar ini merupakan sasaran perlindungan hukum bagi rakyat dan sekaligus membatasi kekuasaan pembentukan undang-undang.

4. Pengawasan pengadilan, sehingga bagi rakyat tersedia saluran pengadilan yang bebas untuk menguji keabsahan tindakan pemerintah (rechtmatigheids toetsing) (Philipus M. Hadjon, $1996: 76)$.

Lebih lanjut, menurut Imannuel Kant dan F.J. Stahl, kriteria untuk dapat disebut negara hukum, harus memenuhi unsur-unsur sebagai berikut :

“1. Jaminan terhadap perlindungan hak-hak asasi manusia;

2. Terselenggaranya pemisahan atau pembagian kekuasaan untuk terselenggaranya hak-hak tersebut di atas;

3. Tiap tindakan pemerintah harus dilandasi undang-undang; dan

4. Adanya peradilan administrasi" (Padmo Wahjono, 1989: 151152).

Berlandaskan pada konsep negara hukum tersebut, maka setelah melalui proses yang panjang, pada tanggal 24 September 1960, Pemerintah mengesahkan Undang-Undang No. 5 Tahun 1960 Tentang Peraturan Dasar Pokok-pokok Agraria. 
Sebagaimana dimuat dalam Penjelasan Umum UUPA, tujuan diundangkannya UUPA, yaitu :

1. Meletakkan dasar-dasar bagi penyusunan Hukum Agraria Nasional, yang akan merupakan alat untuk membawakan kemakmuran, kebahagiaan, dan keadilan bagi negara dan rakyat, terutama rakyat tani dalam rangka masyarakat yang adil dan makmur (Urip Santoso, 2005 : 55-56).

2. Meletakkan dasar-dasar untuk mengadakan kesatuan dan kesederhanaan dalam hukum pertanahan. Oleh karena sebagian besar rakyat Indonesia tunduk pada hukum adat, maka pembentukan Hukum Agraria Nasional didasarkan pada hukum adat sebagaimana tercermin dalam Pasal 5 UUPA (Urip Santoso, $2005: 56$ ).

3. Meletakkan dasar-dasar untuk memberikan kepastian hukum mengenai hak-hak atas tanah bagi rakyat seluruhnya. Upaya untuk mewujudkan tujuan ini, sesuai Pasal 19 ayat (1) UUPA, yang menyebutkan bahwa : “Untuk menjamin kepastian hukum oleh Pemerintah diadakan pendaftaran tanah di seluruh wilayah Republik Indonesia menurut ketentuan-ketentuan yang diatur dengan undang-undang".

Adapun yang dimaksud pendaftaran tanah merupakan suatu rangkaian kegiatan yang dilakukan secara teratur dan terus menerus untuk mengumpulkan, mengolah, menyimpan, dan menyajikan data tertentu 
mengenai bidang-bidang tanah tertentu atau tanah-tanah tertentu yang ada di suatu wilayah tertentu dengan tujuan tertentu.

Menurut Peraturan Menteri Agraria No. 1 Tahun 1961 menyebutkan bahwa objek pendaftaran tanah, yaitu : (1) Bidang tanah yang dipunyai dengan Hak Milik, HGU, HGB, dan Hak pakai; (2) Tanah Hak Pengelolaan; (3) Hak Milik dan Satuan Rumah Susun; (4) Hak tanggungan; dan (4) Tanah Negara

Merujuk pada Pasal 19 UUPA, yang dijabarkan lebih lanjut dalam Peraturan Pemerintah Nomor 24 Tahun 1997 Tentang Pendaftaran tanah, bahwa pendaftaran tanah diselenggarakan dalam rangka menjamin kepastian hukum dan perlindungan hukum kepada pemegang hak atas suatu bidang tanah yang telah terdaftar agar dengan mudah dapat membuktikan dirinya sebagai pemegang hak yang bersangkutan dan bertujuan utuk menyediakan informasi berkenaan dengan hak-hak atas tanah yang telah terdaftar, serta bertujuan untuk tertibnya administrasi pertanahan.

Berbeda dengan Hak Milik, Hak Guna Bangunan, maupun Hak Pakai, perjanjian Bangun Guna Serah (BOT) meskipun objeknya tanah, tetapi bukan merupakan objek pendaftaran tanah.

Tidak didaftarkannya tanah sebagai objek BOT memiliki dampak lemahnya jaminan kepastian hukum dan perlindungan hukum kepada pemegang hak atas suatu bidang tanah yang menjadi objek BOT. Hal tersebut 
mengingat BOT merupakan konsep yang tidak sederhana, karena selain dilakukan dalam 3 tahapan yaitu tahap pembangunan, tahap pengoperasian, maupun tahap penyerahan, juga risiko yang ditanggung para pihak tidak sedikit seperti risiko politik, ekonomi, wanprestasi, overmacht, serta jangka waktu pelaksanaannya yang membutuhkan waktu sekitar 30 (tiga puluh) tahun (Anita Kamilah, $2012: 233$ dan 246).

Sebagai contoh, kasus yang dihadapi para pihak dalam perjanjian kerjasama antara PT. Tritunggal Lestari Makmur dengan Pemerintah Provinsi Jawa Barat untuk melakukan pembangunan gedung perkantoran, gedung konvensi, pusat perdagangan, dan hotel berikut fasilitas pendukungnya melalui Surat Perjanjian Kerjasama No. 593/59 Desen tanggal 26 Mei 2003 tentang Pembangunan, Pengelolaan Dan Penyerahan (Build Operate and Transfer/BOT) Aset Pemerintah Provinsi Jawa Barat yang terletak di Jalan Diponegoro No. 27 dan Jalan Surapati No. 6 Bandung. Di dalam perjanjian yang telah disepakati para pihak, tidak ada satupun klausul yang memberikan kewajiban untuk melakukan pendaftaran objek BOT.

Namun demikian, sejak saat ditandatangani perjanjian antara Pemerintah Provinsi Jawa Barat dengan PT. Tritunggal Lestari Makmur pada tanggal 26 Mei 2003, PT. Tritunggal Lestari Makmur meskipun telah memberikan kontribusi awal sejumlah dana kepada Pemerintah Provinsi Jawa 
Barat, tetapi PT. Tritunggal Lestari Makmur, belum dapat melakukan haknya untuk membangun objek BOT di atas tanah milik Pemerintah tersebut, karena adanya gugatan dari pihak ketiga (masyarakat) atas tanah yang menjadi objek BOT, sehingga pembangunan menjadi terhenti sama sekali, yang berdampak pada kerugian bagi investor.

Mengingat kondisi demikian, untuk memberikan kepastian hukum dan perlindungan terhadap kedudukan para pihak dalam perjanjian BOT, yaitu pemilik hak atas tanah maupun investor, juga pihak-pihak lainnya yang terlibat seperti pihak kontraktor, pihak penyewa, pihak bank, dan pihak asuransi untuk secermat dan seteliti mungkin dalam mencantumkan klausulklausul perjanjian BOT, sehingga hak-hak dan kewajiban para pihak terlindungi.

Hal tersebut sesuai dengan ketentuan Pasal 1320 KUH Perdata, dan Pasal 1338 ayat (1) KUH Perdata. Pasal 1320 ayat (1) KUH Perdata, menyebutkan bahwa : “Untuk sahnya suatu perjanjian diperlukan sepakat mereka yang mengikatkan dirinya. Kemudian Pasal 1338 ayat (1) KUH Perdata menyebutkan bahwa : "Semua perjanjian yang dibuat secara sah berlaku sebagai undang-undang bagi mereka yang membuatnya" (R. Subekti, $1992: 5)$

Selanjutnya, sesuai Pasal 1338 ayat (3) KUH Perdata, semua perjanjian harus dilaksanakan dengan itikad baik (te goeder trouw). Subekti, 
menyebutkan bahwa itikad baik yang disebut dalam bahasa Belanda dengan te goeder trouw, sebagai suatu sendi yang terpenting di dalam hukum perjanjian (R. Subekti, 1992 : 41). Kemudian, sesuai asas Pacta Sunt Servanda berasal dari aturan lama dalam hukum Romawi/Latin yang merupakan acuan bahwa terhadap setiap perjanjian, masing-masing pihak harus menepati janjinya untuk melaksanakan kewajibannya dan menghormati hak pihak lain.

Apabila mengindentifikasi secara seksama ciri-ciri proyek BOT, yang pelaksanaannya terdiri dari 3 (tiga) tahapan, yaitu tahap pembangunan (Build), tahap pengoperasian (Operate), dan tahap penyerahan (Transfer), maka aspek-aspek hukum perjanjian yang berkaitan dengan pemanfaatan tanah melalui konsep BOT, di dalamnya memiliki keterkaitan dengan perjanjian-perjanjian sebagaimana disebutkan di atas, yaitu :

a. Perjanjian Pemborongan Pekerjaan.

Perjanjian Pemborongan Pekerjaan diatur dalam Buku III KUH Perdata tentang Perikatan (van verbintenissen) Bab VII A, Pasal 1601 b KUH Perdata, yang menyebutkan bahwa Pemborongan Pekerjaan adalah :

“Perjanjian, dengan mana pihak yang satu, si pemborong mengikatkan diri untuk menyelenggarakan suatu pekerjaan bagi pihak yang lain, pihak yang memborongkan, dengan menerima suatu harga yang ditentukan".

Adanya keterkaitan antara perjanjian Bangun Guna Serah (Build Operate and Trasnfer/BOT) dengan perjanjian pemborongan pekerjaan karena lajimnya pihak investor yang memperoleh hak penuh untuk men- 
dirikan proyek infrastruktur dari pihak pemilik hak atas tanah (pemerintah/swasta) ini, pada umumnya tidak mengerjakan sendiri pekerjaan-pekerjaan pembangunan proyek tersebut, tetapi dilakukan dengan penunjukkan pemborong/ kontraktor melalui perjanjian pemborongan pekerjaan dimana si pemborong mengikatkan diri pada investor untuk melakukan pekerjaan pembangunan proyek BOT dan sekaligus sebagai perencana untuk pengerjaan bagian-bagian utama proyek dengan menerima suatu imbalan tertentu.

Pihak pemborong/kontraktor hanya memiliki hubungan hukum dengan pihak investor saja, sebagai pihak yang memberikan kuasa kepadanya untuk dan atas nama investor melakukan pekerjaan pembangunan proyek. Namun demikian, dalam suatu perjanjian BOT yang dilakukan antara pemilik hak atas tanah dengan pihak investor, dapat dimuat suatu klausul yang menyebutkan bahwa selama masa pembangunan, pihak pemilik hak atas tanah diberikan kewenangan melakukan pengawasan terhadap pekerjaan yang dilakukan pemborong. Oleh karena itu, jika selama pengawasan dilakukan, ada pengerjaan pembangunan proyek yang tidak sesuai dengan apa yang telah diperjanjikan, maka pihak pemilik tanah dapat meminta pertanggungjawaban kepada pihak investor bukan kepada pihak pemborong. 
b. Perjanjian Kredit Perbankan.

Pembiayaan proyek BOT sebagian besar lajimnya dibiayai melalui modal pihak swasta, namun jika dana yang disediakan pihak investor bagi pelaksanaan proyek BOT tersebut belum optimal, maka dibutuhkan alternatif pembiayaan lainnya yaitu dengan menggunakan pinjaman dari pihak ketiga atau pihak bank. Pihak pemberi pinjaman (project lender) bertindak sebagai kreditur dan pihak investor sebagai debitur. Project lender berkewajiban untuk memberikan sejumlah uang untuk membiayai proyek, sedangkan pihak investor berkewajiban membayar kembali pinjaman sesuai dengan dokumen pembiayaan yang telah disepakati, sehingga berlaku ketentuan tentang pinjam-meminjam Pasal 1754-Pasal 1769 KUH Perdata, dan jika pihak pemberi pinjaman proyek berupa suatu bank maka berlaku ketentuan-ketentuan perkreditan yang diatur dalam peraturan perbankan Undang-Undang No. 7 Tahun 1992 sebagaimana telah diubah dengan Undang-Undang No. 10 Tahun 1998 Tentang Perbankan (Munir Fuady, 1997 : 8).

c. Perjanjian Asuransi/Pertanggungan.

Keterlibatan pihak asuransi dalam perjanjian BOT pun tidak dapat diabaikan begitu saja, mengingat waktu pelaksanaan perjanjian BOT selama 30 (tiga puluh) tahun tersebut, perlu adanya jaminan kepastian hokum berkaitan dengan pihak yang akan melakukan penanggungan 
terhadap klaim-klaim risiko yang terjadi pada objek BOT. Oleh karena itu, para pihak lajimnya menentukan dalam klausul perjanjian BOTnya untuk mewajibkan pihak investor mengasuransikan objek BOT, sehingga terciptalah hubungan hukum pertanggungan atau perjanjian asuransi.

Sesuai ketentuan Pasal 1 ayat (1) Undang-Undang No. 2 Tahun 1992 Tentang Usaha Perasuransian, menyebutkan bahwa :

“Asuransi atau Pertanggungan adalah perjanjian antara dua pihak atau lebih, dengan mana pihak penanggung mengikatkan diri kepada tertanggung, dengan menerima premi asuransi, untuk memberikan penggantian kepada tertanggung karena kerugian, kerusakan atau kehilangan keuntungan yang diharapkan, atau tanggung jawab hukum kepada pihak ketiga yang mungkin diderita tertanggung, yang timbul dari suatu peristiwa yang tidak pasti, atau untuk memberikan suatu pembayaran yang didasarkan atas meninggal atau hidupnya seseorang yang dipertanggungkan".

d. Perjanjian Sewa Menyewa.

Kemudian, sebagai kontra prestasi yang diberikan oleh pemilik hak atas tanah kepada investor yang telah mendanai pembangunan proyek BOT tersebut, maka pihak investor diberikan hak pemanfaatan objek BOT, selain untuk menutupi pendanaan yang telah dikeluarkan dalam membiayai objek BOT, juga sekaligus untuk memperoleh keuntungan dari dan dalam pengelolaan proyek, melalui perjanjian sewa menyewa. Dalam perjanjian sewa menyewa tersebut, pihak investor berkedudukan sebagai pihak yang menyewakan, dan pihak pengguna (user) sebagai pihak penyewa. 
Pertanyaan menarik berkaitan dengan perjanjian sewa menyewa ini, apakah perjanjian sewa menyewa dalam konsep BOT termasuk dalam pengaturan hukum privat atau hukum tanah.

Di dalam Buku III KUH Perdata tentang Perikatan (Van Verbintenissen), perjanjian sewa menyewa diatur dalam Pasal 1548 sampai dengan Pasal 1600.

Menurut ketentuan Pasal 1548 KUH Perdata, disebutkan bahwa :

"Sewa menyewa adalah suatu perjanjian, dengan mana pihak yang satu mengikatkan dirinya untuk memberikan kepada pihak yang lainnya kenikmatan dari suatu barang, selama suatu waktu tertentu dan dengan pembayaran sesuatu harga, yang oleh pihak tersebut belakang itu disanggupi pembayarannya".

Menjawab pertanyaan di atas, dapat dikaji pada bunyi konsideran UUPA yang menyebutkan bahwa Buku ke II Kitab Undang-Undang Hukum Perdata, sepanjang yang mengenai bumi, air, serta kekayaan alam yang terkandung di dalamnya, kecuali ketentuan-ketentuan mengenai hipotek yang masih berlaku pada mulai berlakunya undang-undang ini.

Berdasarkan pada uraian di atas, dapat dianalisis bahwa meskipun KUH Perdata mengatur perjanjian sewa menyewa, tetapi mengingat objek BOT adalah tanah, maka ketentuan sewa menyewa dalam Pasal 1548 sampai dengan Pasal 1600 KUH Perdata tidak dapat diberlakukan pada BOT, karena ketentuan sewa menyewa atas tanah/bangunan sudah diatur secara khusus dalam Bab VII Pasal 44 sampai dengan Pasal 45 UUPA. 
Adapun bunyi Pasal 44 ayat (1) UUPA adalah sebagai berikut: "Seseorang atau suatu badan hukum mempunyai hak sewa atas tanah, apabila ia berhak mempergunakan tanah milik orang lain untuk keperluan bangunan, dengan mambayar kepada pemiliknya sejumlah uang sebagai sewa". Gambaran tersebut dalam konsep hukum dikenal dengan adagium "Lex specialis derogat lex generalis, bahwa apabila ketentuan khusus telah mengaturnya secara tersendiri, maka ketentuan umum dalam hal ini KUH Perdata dikesampingkan."

Kemudian, jika konsep BOT dianalisis dari Pembahasan sub A maupun sub B, objek BOT selain termasuk Private Rechtelijk juga Hukum Administrasi Negara. Private Rechtelijk, karena BOT merupakan hukum yang mengatur kepentingan antara warga negara perseorangan yang satu dengan warga negara perseorangan yang lain, yang menimbulkan hak-hak dan kewajiban kepada para pihak, yang diatur secara umum dalam Buku III KUH Perdata Tentang Perikatan (Van Verbitenissen).

Kemudian konsep BOT yang objeknya tanah juga termasuk ke dalam hukum Publik, hal ini sesuai dengan pendapat Boedi Harsono, bahwa lingkup hukum di bidang agraria, tidak hanya hukum perdata (hukum agraria/tanah perdata), tetapi juga hukum publik di bidang administrasi negara (hukum agraria administratif). 
Pandangan yang sama diberikan oleh Subekti dan Tjitrosudibio, yang memberikan arti yang luas pada hukum agraria, karena mencakup seluruh ketentuan, baik hukum perdata, hukum tata negara maupun hukum tata usaha negara, yang mengatur hubungan-hubungan antara orang, termasuk badan hukum dengan bumi, air, dan ruang angkasa dalam seluruh wilayah negara dan mengatur pula wewenang yang bersumber pada hubungan-hubungan tersebut (R. Subekti dan R. Tjitrosudibio, 1983 $: 12)$.

Kemudian, jika dianalisis dari macam-macam hak atas tanah, BOT merupakan hak derivatif di atas hak original, yang sifatnya sementara, karena BOT merupakan hak turunan dari hak yang ada sebelumnya, baik itu hak milik, hak pakai, maupun hak pengelolaan. Kemudian, sifatnya sementara, karena setelah masa BOT selesai, pemegang hak derivatif dalam hal ini dipegang oleh pihak ketiga (investor) sebagai pihak yang mendanai BOT, harus mengembalikan tanah kepada pemiliknya tanpa pemilik tanah mengeluarkan sejumlah uang tertentu. 


\section{SIMPULAN DAN SARAN}

\section{A. Simpulan}

1. Sebagai suatu perjanjian, konsep BOT tidak diatur secara khusus dalam Buku III KUH Perdata tentang Perikatan (Van Verbintenissen), namun ketentuan Pasal 1338 yang dikenal dengan asas kebebasan berkontrak dapat dijadikan sebagai dasar berlakunya BOT. Demikian juga, sebagai perjanjian yang objeknya tanah UUPA pun sama seperti Buku III KUH Perdata tentang Perikatan (Van Verbintenissen) tidak secara tegas memberikan pengaturan tentang BOT sendiri. Namun demikian, meskipun UUPA tidak mengatur secara tegas tentang BOT, apabila mengkaji ketentuan Pasal 20 UUPA tentang hak milik, dapat dijadikan dasar berlakunya ketentuan BOT, karena pemilikan atas tanah sebagai salah satu hak asasi manusia, dapat dimanfaatkan oleh pemiliknya dalam berbagai aspek kehidupan baik dalam aspek ekonomi, aspek sosial, termasuk dalam hubungannya dengan pembangunan melalui konsep BOT. Selain itu, ketentuan Pasal 35 UUPA tentang Hak Guna Bangunan dapat menjadi dasar berlakunya BOT, karena apabila seseorang menggunakan tanah yang langsung dikuasai langsung oleh negara atau tanah milik orang lain, yang didasarkan pada Hak Pakai, maupun Hak Pengelolaan, lajimnya di atas tanah yang dimanfaatkan melalui konsep BOT tersebut, diletakkan Hak Guna Bangunan. 
2. Pendaftaran tanah merupakan suatu rangkaian kegiatan yang dilakukan secara teratur dan terus menerus untuk mengumpulkan, mengolah, menyimpan, dan menyajikan data tertentu mengenai bidang-bidang tanah tertentu atau tanah-tanah tertentu yang ada di suatu wilayah tertentu dengan tujuan untuk menjamin kepastian hukum dan perlindungan hukum kepada pemegang hak atas suatu bidang tanah yang telah terdaftar agar dengan mudah dapat membuktikan dirinya sebagai pemegang hak yang bersangkutan. Selain itu, bertujuan utuk menyediakan informasi berkenaan dengan hak-hak atas tanah yang telah terdaftar, serta tertibnya administrasi pertanahan. Berbeda dengan Hak Milik, Hak Guna Bangunan, maupun Hak Pakai, perjanjian Bangun Guna Serah (BOT) meskipun objeknya tanah, tetapi bukan merupakan objek pendaftaran tanah. Tidak didaftarkannya tanah sebagai objek BOT memiliki dampak lemahnya jaminan kepastian hukum dan perlindungan hukum kepada pemegang hak atas suatu bidang tanah yang menjadi objek BOT. Hal tersebut mengingat BOT merupakan konsep yang tidak sederhana, karena selain dilakukan dalam 3 (tiga) tahapan yaitu tahap pembangunan, tahap pengoperasian, maupun tahap penyerahan, juga risiko yang ditanggung para pihak tidak sedikit seperti risiko politik, ekonomi, wanprestasi, overmacht, serta jangka waktu pelaksanaannya yang membutuhkan waktu sekitar 30 (tiga puluh) tahun. Mengingat 
kondisi demikian, untuk memberikan kepastian hukum dan perlindungan terhadap kedudukan para pihak dalam perjanjian BOT, yaitu pemilik hak atas tanah maupun investor, juga pihak-pihak lainnya yang terlibat seperti pihak kontraktor, pihak penyewa, pihak bank, dan pihak asuransi untuk secermat dan seteliti mungkin dalam mencantumkan klausul-klausul perjanjian BOT, sehingga hak-hak dan kewajiban para pihak terlindungi.

\section{B. Saran}

1. Mengingat konsep Bangun Guna Serah (Build Operate and Transfer/BOT) memiliki peran yang cukup besar dalam mendukung pelaksanaan pembangunan nasional dalam menjembati keterbatasan penyediaan lahan strategis maupun keterbatasan dana/modal, maka untuk memberikan kepastian hukum terhadap ketersediaan lahan strategis tersebut dan kepastian hubungan hukum para pihak dalam perjanjian BOT, perlu didukung oleh kebijakan pemerintah dalam bentuk undang-undang sebagai aturan yang secara khusus mengatur perjanjian Bangun Guna Serah (Build Operate and Transfer/BOT).

2. Mengingat pemanfaatan tanah melalui konsep perjanjian Bangun Guna Serah (Build Operate and Transfer/BOT) ini merupakan perjanjian yang tanahnya tidak terdaftar dalam sistem pendaftaran tanah, serta memiliki karakteristik yang khas yang pelaksanaannya terdiri dari 3 (tiga) tahapan, 
mulai tahap pembangunan, tahap pengoperasian dan tahap penyerahan, maka baik pemerintah maupun masyarakat sebelum melakukan perjanjian BOT disarankan memiliki pemahaman yang baik berkaitan dengan isi perjanjian BOT sehingga dapat melindungi hak-hak dan kewajiban para pihak.

\section{DAFTAR PUSTAKA}

Aslan Noor, 2006, Konsep Hak Milik Atas Tanah Bagi Bangsa Indonesia Ditinjau Dari Ajaran Hak Asasi Manusia, Bandung, CV. Mandar Maju.

Arie Sukanti Hutagalung dan Markus Gunawan, 2009, Kewenangan Pemerintah Di Bidang Pertanahan, Jakarta, PT. Raja Grafindo.

Anita Kamilah, 2012, Bangun Guna Serah (Build Operate and Transfer/BOT) Membangun Tanpa Harus Memiliki Tanah (Perspektif Hukum Agraria, Hukum Perjanjian, Dan Hukum Publik), Bandung, Keni Media.

Bagir Manan, 1996, Politik Perundang-undangan Dalam Rangka Mengantisipasi Liberalisasi Perekonomian, Fakultas Hukum UNILA, Lampung.

Budi Santoso, 2008, Aspek Hukum Pembiayaan Proyek Infrastruktur Dengan Model BOT (Build Operate and Transfer), Yogyakarta, Genta Press.

Bieker. Neil, 1997, Cessie Boggs, Foreign Investment in Privatised Infrastructure Projects, Jakarta, Hadinoto, Hadiputranto \& Partners. 
Boedi Harsono, 1999, Hukum Agraria Indonesia : Sejarah Pembentukan UUPA, Isi dan Pelaksanaannya, Cetakan kedelapan, (Edisi Revisi), Jakarta, Djambatan.

C.F.G. Sunaryati Hartono, 1991, Politik Hukum Menuju Satu Sistem Hukum Nasional, Bandung, Alumni.

Darji Darmodiharjo dan Sidharta, 1996, Penjabaran Nilai-nilai Pancasila Dalam Sistem Hukum Indonesia, Jakarta, PT. RajaGrafindo Persada. , 2004, Pokok-pokok Filsafat Hukum, Apa Dan Bagaimana Filsafat Hukum Indonesia, Jakarta, PT. Gramedia.

H. Ali Achmad Chomzah, 2000, Hukum Pertanahan Seri Hukum Pertanahan I (Pemberian Hak Atas Tanah Negara) Dan Seri Hukum Pertanahan II (Sertifikat dan Permasalahannya), Jakarta, Prestasi Pustaka.

Lili Rasjidi, 1985, Dasar-dasar Filsafat Hukum, Bandung, Alumni.

Lili Rasjidi dan Ira Thania, 2002, Pengantar Filsafat Hukum, Cetakan Kedua, Bandung, Mandar Maju.

, 2007, Dasar-dasar Filsafat Dan Teori Hukum, Cetakan Kesepuluh, Bandung, Citra Aditya Bakti.

Lili Rasjidi dan Wiyasa Putra, 2003, Hukum Sebagai Suatu Sistem, Cetakan Ketiga, Bandung, Mandar Maju.

Locke. John, 1960, Two Treaties of Civil Govermment, London, J.M. Dent \& Sons Ltd. 
Mochtar Kusumaatmadja, 2006, Konsep-konsep Hukum Dalam Pembangunan, Bandung, PT. Alumni. , 1976, Hukum, Masyarakat, dan Pembinaan Hukum Nasional Suatu Uraian Tentang Landasan Pikiran, Pola dan Mekanisme Pembaharuan Hukum di Indonesia, Bandung, Lembaga Penelitian Hukum dan Kriminologi, Fakultas Hukum Universitas Padjadjaran.

Muchsin, Iman Koeswahyono, dan Soimin, 2007, Hukum Agraria Indonesia Dalam Perspektif Sejarah, Bandung, PT. Refika Aditama.

Munir Fuady, 2007, Dinamika Teori Hukum, Bogor, Ghalia Indonesia.

Mariam Darus Badrulzaman, 1996, KUH Perdata Buku III Hukum Perikatan Dengan Penjelasan, Bandung, Alumni.

Philipus M. Hadjon, 1996, Ide Negara Hukum Dalam Sistem Ketatanegaraan Republik Indonesia, dalam Bagir Manan (Editor) Kedaulatan Rakyat, Hak Asasi Manusia dan Negara Hukum, Jakarta, Gaya Media Pratama.

R. Soeprapto, 1986, Undang-Undang Pokok Agraria Dalam Praktik, Jakarta, UI Press.

R. Setiawan, 1978, Pokok-pokok Hukum Perikatan, Bandung, Binacipta.

R. Soetojo Prawirohamidjojo, 1979, Hukum Perikatan, Surabaya, Bina IImu.

Sjachran Basah, 1986, Eksistensi Dan Tolok Ukur Badan Peradilan Administrasi Di Indonesia, Bandung, Alumni.

Urip Santoso, 2005, Hukum Agraria Dan Hak-hak Atas Tanah, Jakarta, Prenada.

W.J.S. Poerwadarminta, 1976, Kamus Umum Bahasa Indonesia, Jakarta, Balai Pustaka. 